\title{
Dominant perivenular enhancement of tumefactive demyelinating lesions in multiple sclerosis
}

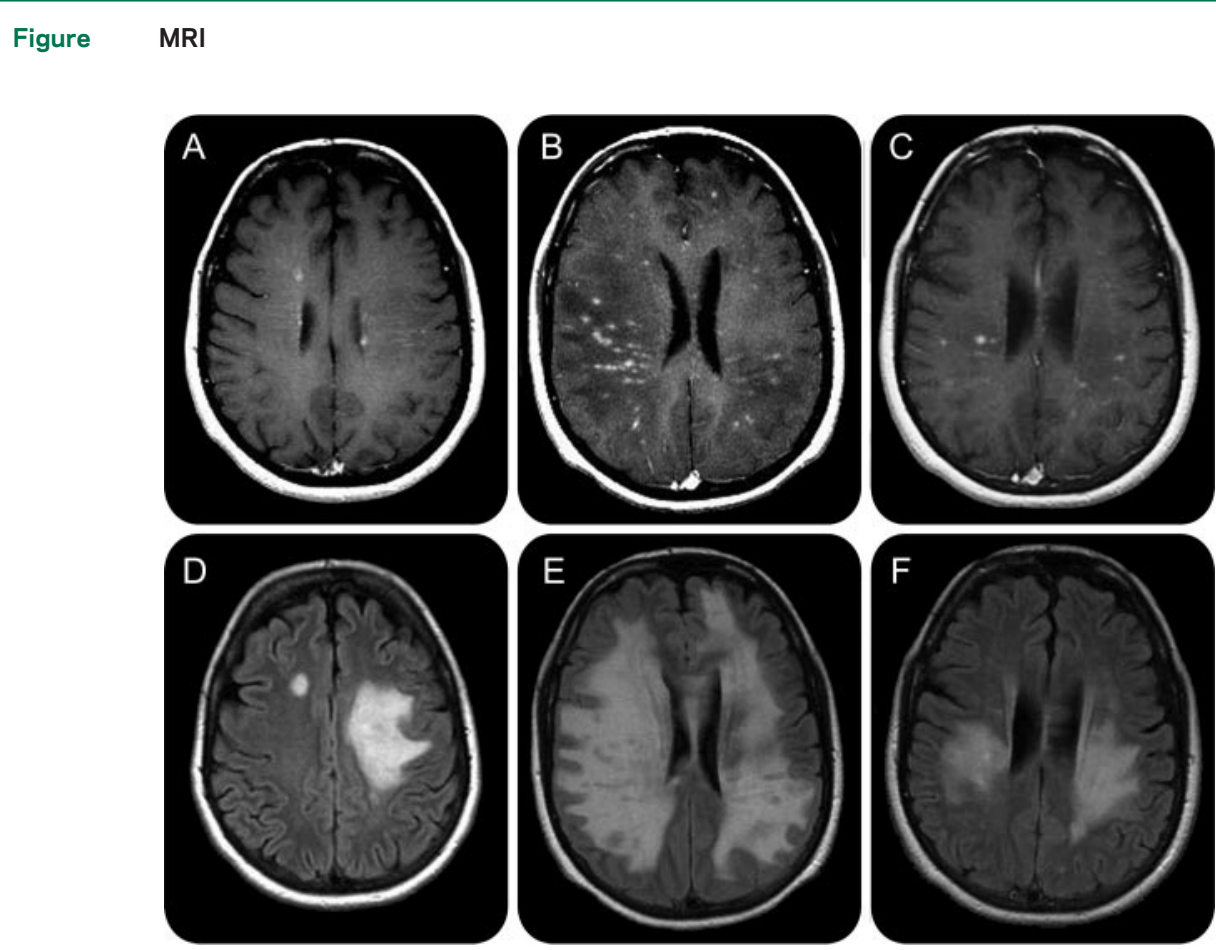

Postcontrast T1 (top) and fluid-attenuated inversion recovery (FLAIR) images (bottom) demonstrate temporal evolution (left to right) of the tumefactive lesions. While large confluent FLAIR lesions (D-F) are seen occasionally, dominant perivascular enhancements $(A-C)$ indicating severe acute inflammation are rare in multiple sclerosis, which may represent aggressive disease course and require immediate attention.

A 51-year-old woman presented with aphasia and bifrontal MRI lesions with punctuate and vague linear enhancement (figure). She improved spontaneously but 4 months later deteriorated due to the large mass and required cranial decompression. Innumerable, perivenular enhancements perpendicular to the lateral ventricles were seen within extensive bihemispheric white matter lesions. Multiple sclerosis (MS) was diagnosed based on typical inflammatory demyelination at biopsy, CSF oligoclonal bands, and a previous CNS event. Treatment with mitoxantrone and Copaxone followed. MRI lesions improved rapidly. She remains stable with minimal deficit (Expanded Disability Status Scale 1.0) 2 years later. Dominant perivenular enhancements are atypical for $\mathrm{MS}^{1,2}$ but deserve recognition, although they may not prevent biopsy.

\section{Y. Zhang, MD, PhD, L.M. Metz, MD, FRCPC, Calgary, Canada}

Disclosure: Dr. Zhang has received fellowship grants from Biogen Idec, Teva Pharmaceutical Industries Ltd., and the Multiple Sclerosis Society of Canada. Dr. Metz serves on scientific advisory boards for Teva Pharmaceutical Industries Ltd. and the NIH/ NINDS/NMSS; has received speaker honoraria from Teva Pharmaceutical Industries Ltd.; serves on the editorial board of Multiple Sclerosis; has served as a consultant for Teva Pharmaceutical Industries Ltd. and EMD Serono, Inc.; and receives research support from Biogen Idec, Bayer Schering Pharma, Teva Pharmaceutical Industries Ltd., Alberta Health Services, the Multiple Sclerosis Society of Canada, Neuroscience Canada, the Stem Cell Network, and the Canadian Institute of Health Research.

Address correspondence and reprint requests to Dr. Yunyan Zhang, 182B Heritage Medical Research Building, 3330 Hospital Dr. NW, Calgary AB T2N 1N4Canada; yunyzhan@ucalgary.ca

1. Cha S, Pierce S, Knopp EA, et al. Dynamic contrast-enhanced T2*-weighted MR imaging of tumefactive demyelinating lesions. AJNR Am J Neuroradiol 2001;22:1109-1116.

2. Given CA II, Stevens BS, Lee C. The MRI appearance of tumefactive demyelinating lesions. AJR Am J Roentgenol 2004;182: $195-199$. 


\section{Neurology}

\section{Dominant perivenular enhancement of tumefactive demyelinating lesions in multiple sclerosis}

Y. Zhang and L.M. Metz

Neurology 2010;75;1396

DOI 10.1212/WNL.0b013e3181f736d3

\section{This information is current as of October 11, 2010}

\section{Updated Information \&} Services

References

Citations

Subspecialty Collections

Permissions \& Licensing

Reprints including high resolution figures, can be found at: http://n.neurology.org/content/75/15/1396.full

This article cites 2 articles, 0 of which you can access for free at: http://n.neurology.org/content/75/15/1396.full\#ref-list-1

This article has been cited by 1 HighWire-hosted articles: http://n.neurology.org/content/75/15/1396.full\#\#otherarticles

This article, along with others on similar topics, appears in the following collection(s):

\section{Autoimmune diseases}

http://n.neurology.org/cgi/collection/autoimmune_diseases

MRI

http://n.neurology.org/cgi/collection/mri

Multiple sclerosis

http://n.neurology.org/cgi/collection/multiple_sclerosis

Information about reproducing this article in parts (figures,tables) or in its entirety can be found online at:

http://www.neurology.org/about/about_the_journal\#permissions

Information about ordering reprints can be found online:

http://n.neurology.org/subscribers/advertise

Neurology ${ }^{\circledR}$ is the official journal of the American Academy of Neurology. Published continuously since 1951, it is now a weekly with 48 issues per year. Copyright Copyright (? 2010 by AAN Enterprises, Inc.. All rights reserved. Print ISSN: 0028-3878. Online ISSN: 1526-632X.

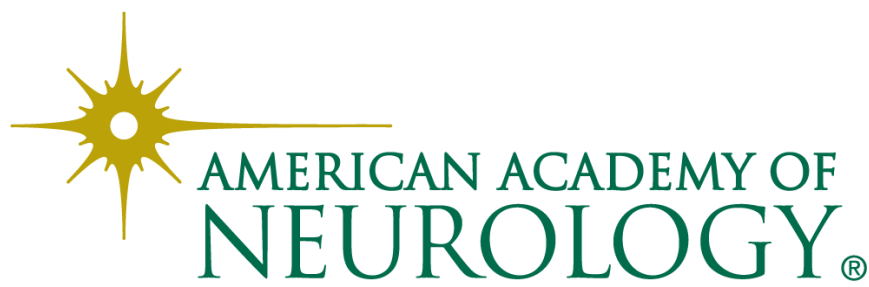

